\title{
Effect of Adding Palm Oil Mill Effluent (POME) and Slurry on Biogas From Cow Manure to Produced Methane Gas
}

\author{
Muhammad Hanif Fatin ${ }^{1, *}$ A. Husaini ${ }^{2}$ Leila Kalsum ${ }^{3}$ \\ ${ }^{1}$ Applied Renewable Energy Engineering Study Program, Politeknik Negeri Sriwijaya, Jalan Srijaya Negera, \\ Palembang, 30139 Indonesia \\ ${ }^{2}$ Chemical Engineering Department, Politeknik Negeri Sriwijaya, Jalan Srijaya Negara, Palembang, 30139 \\ Indonesia. \\ ${ }^{3}$ Renewable Energy Engineering Department, Politeknik Negeri Sriwijaya, Jalan Srijaya Negara, Palembang, 30139 \\ Indonesia. \\ *Corresponding author. Email: fatin.hanif97@gmail.com
}

\begin{abstract}
Biogas is a renewable energy source that is environmentally friendly and economical. High of Palm Oil Mill Effluent (POME) and cow manure have great potential as a source of raw material for making biogas. The purpose of this study was to determine the effect of the addition of POME and biogas slurry to the production of biogas from cow manure raw material. The composition of raw materials used are $40 \mathrm{~L}$ cow manure, $20 \mathrm{~L}$ water, $20 \mathrm{~L}$ POME in the first experiment and $40 \mathrm{~L}$ cow manure, $20 \mathrm{~L}$ water, $20 \mathrm{~L}$ biogas slurry in the second experiment. The composition of methane gas was analyzed using the Gas Chromatography. From the results obtained, the addition of POME produced $64.65 \%$ of methane gas with biogas production of $54 \mathrm{~L}$ and the addition of biogas slurry produced $53.83 \%$ of methane gas with biogas production of $58 \mathrm{~L}$.
\end{abstract}

Keywords: Biomass, Renewable Energy, Biogas, POME

\section{INTRODUCTION}

Energy is a very important issue in the world is no exception in Indonesia, as the country with the largest energy consumption in the Southeast Asia region and fifth in the Asia Pacific in primary energy consumption, after the countries of China, India, Japan and South Korea. High Gross Domestic Product (GDP) growth, reaching an average of $6.04 \%$ per year over the 2017 2050 period. This causes an increase in Indonesia's energy needs in the future. In Government Regulation No. 79 of 2014 on National Energy Policy to prioritize the development of Indonesian energy that includes several things, namely the maximum use of renewable energy by paying attention to the economic level, minimizing the use of petroleum, natural gas utilization and new energy optimally, and make coal as the mainstay of the national energy supply [1].

The limitation of fossil energy requires diversification of energy resources in order to guarantee the availability of energy. Then the use of new and renewable energy must be intensified. Renewable energy is one of the options for the energy needs of the future. Although it is based only on solar energy and the energy source is clean and infinitely, this solution has a number of problems in everyday life that have to be considered. The problems are related to resources, limited potential, base load, the grid, and primary resources [2].

One of the renewable energy that can be produced with appropriate technology that is relatively simpler for environmentally friendly and economical is biomass energy. Biomass energy sources that have great potential especially in Indonesia include biodiesel and biogas. Biodiesel is an alternative fuel sourced from plant and animal fats, Crude Palm Oil (CPO), waste cooking oil, and algal plants, while it is predicted that biodiesel consumption in Indonesia in 2025 will rise to 6.9 million kiloliters [3-6]. Biogas is a renewable energy that is formed from the anaerobic digestion process which is a microbiological process of decomposing organic matter without oxygen in a reactor and can be used as fuel [7-9].

Biogas production generally uses organic materials such as livestock waste, agriculture and industrial waste. In Indonesia, the amount of cow manure is always 
increasing and most of it is left alone without further processing. This can be processed anaerobic digestion to reduce waste and can also produce biogas as a renewable energy source [10]. The composition of biogas consists of methane $(50-70 \% \mathrm{vol})$, carbon dioxide (25-50\% vol) and other gases such as hydrogen, and hydrogen sulfide [9][11-14].

In the last few years palm oil has developed very rapidly in the world and is controlled by Indonesia and Malaysia. 90 percent of palm oil production is dominated by the Indonesian state at 34.52 million tons and Malaysia at 17.32 million tons in 2016 [15]. On the other hand a very large production volume will release large quantities of palm oil mill effluent (POME). POME is a highly polluting waste due to high concentrations of COD, BOD and color, which can affect the environment, especially water sources. However, it is recognized as a renewable biogas source such as biomethane and biohydrogen [16][17].

Meanwhile according to [18], pretreatment in the form of setting the $\mathrm{pH}$ value in POME to increase biogas production by using an up-flow sludge blanket (UASB) type bioreactor. It is known that the $\mathrm{pH}$ characteristics possessed are acidic in the range of 3.45.2 which in the process of biogas formation requires microorganisms that can live at a certain $\mathrm{pH}$. POME results were obtained which decreased the COD value by 96 percent with the addition of $\mathrm{NaOH}$ as a regulator of the $\mathrm{pH}$ value.

In general, methane-producing bacteria are sensitive to $\mathrm{pH}$ changes and have an optimum $\mathrm{pH}$ range of 6.58.5. Under this $\mathrm{pH}$ the decomposition can proceed but the decomposition efficiency will decrease rapidly and will produce acidic conditions which will inhibit the growth of methanogenetic bacteria. If the growth of methane bacteria is inhibited, the rate of decomposition of volatile acids will decrease so there will be accumulation of volatile acids [19][20].

The use of POME as a raw material for making biogas has been widely developed. Among them making biogas from POME raw material with a mixture of oil palm bunches with variations in the size of oil palm bunches in a batch type bioreactor feed mixture. The optimal size of oil palm bunches in making biogas is 0.2 $\mathrm{mm}$ with a yield of $320 \mathrm{~mL}$ of methane with a gas concentration of 63-70 percent [21].

Making biogas from POME with and without a mixture of deer manure in a bioreactor type contuinuosly stirred tank reactor (CSTR). It was found that the mixture of POME and deer manure produced $0.85 \mathrm{~L} /$ day of methane gas with a concentration of 59 percent compared to without deer manure which only produced 0.39 L/day of methane gas with a concentration of 20 percent where deer manure also accelerated the process of forming biogas [22].
In this paper carried out research biogas production using cow manure with the addition does POME and slurry in the mixture. The use of cow dung as the main raw material is due to the high population of cattle in Indonesia with a population increase of $4.7 \%$ per year [23]. While the addition of slurry to the mixture of raw materials can increase the rate and yield of biogas production [24][25].

\section{RESEARCH METHODS}

The tool used in this study is a prototype fixed dome type biodigester with a capacity of 100 liters equipped with a pressure gauge, $\mathrm{pH}$ and temperature control on the biodigester which can be seen in Figure 1.

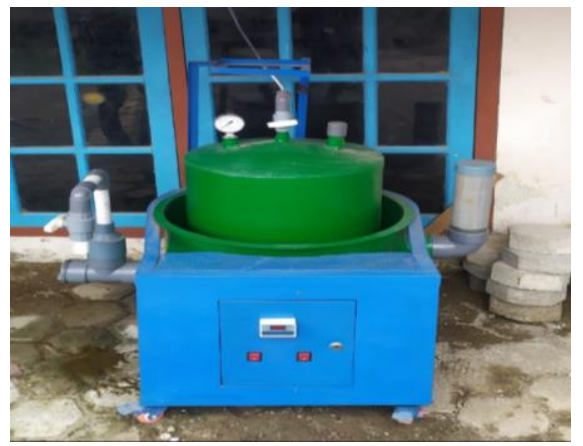

Figure 1. Prototype fixed dome biodigester

The raw material for cow manure is taken from one of the cattle farms in the macan lindungan area, Palembang and POME at PT. Sriwijaya Palm Oil Indonesia Banyuasin, South Sumatra. The first experiment, a mixture of raw materials in the form of cow dung of $40 \mathrm{~L}$ and $20 \mathrm{~L}$ of water was put into biodigester with $20 \mathrm{~L}$ POME added. Whereas in the second experiment a mixture of cow dung of $40 \mathrm{~L}$ and $20 \mathrm{~L}$ of water added $20 \mathrm{~L}$ of slurry biogas from the first experiment.

During the fermentation process, raw materials were analyzed every 5 days with analysis in the form of Chemical Oxygen Demand (COD), Total Suspended Solid (TSS) and Volatile Suspended Solid (VSS) which were carried out at the Chemical Engineering Laboratory of Sriwijaya State Polytechnic Palembang.

The results of biogas production during the fermentation process are analyzed at intervals every 5 days using the SHIMADZU GC-2014 Gas Chromatography at PT. Pupuk Sriwidjaja Palembang to determine the composition of biogas with parameters such as $\mathrm{CH}_{4}, \mathrm{CO}_{2}, \mathrm{O}_{2}$ and $\mathrm{N}_{2}$. 


\section{RESULT AND DISCUSSION}

\subsection{Biogas Composition Analysis}

The results of the biogas composition in the mixture of raw materials for cow manure and POME which have been analyzed by gas chromatography every 5 days for 35 days of the fermentation process with the highest methane content of $64.65 \%$ on the 30th day which can be seen in Figure 2.
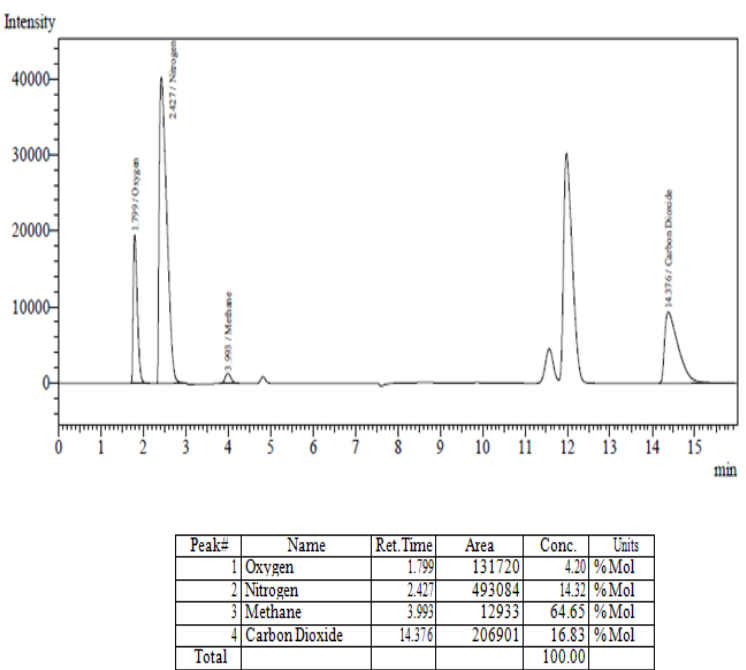

Figure 2. Biogas Composition Analysis Result From Cow Manure and POME at $30^{\text {th }}$ day

All biogas composition analysis results from cow manure and POME for 35 days of fermentation can be seen in Table 1.

Table 1. Biogas Composition Analysis Result From Cow Manure and POME

\begin{tabular}{|c|c|c|c|c|}
\hline Day & \multicolumn{4}{|c|}{ Biogas Composition (\%) } \\
\hline & $\mathrm{CH}_{4}$ & $\mathrm{CO}_{2}$ & $\mathrm{O}_{2}$ & $\mathrm{~N}_{2}$ \\
\hline 0 & 0 & 0 & 0 & 0 \\
\hline 5 & 0 & 0 & 0 & 0 \\
\hline 10 & 16.35 & 0.23 & 21.9 & 61.06 \\
\hline 15 & 20.28 & 0.85 & 19.64 & 59.19 \\
\hline 20 & 31.60 & 1.92 & 16.25 & 50.23 \\
\hline 25 & 42.54 & 3.03 & 13.72 & 40.71 \\
\hline 30 & 64.65 & 16.83 & 4.20 & 14.32 \\
\hline 35 & 62.17 & 28.61 & 2.18 & 7.04 \\
\hline
\end{tabular}

In the mixture of raw materials for cow manure and slurry, the fermentation process occurred for 30 days with the highest methane content of $53.83 \%$ on the 25 th day which can be seen in Figure 3.

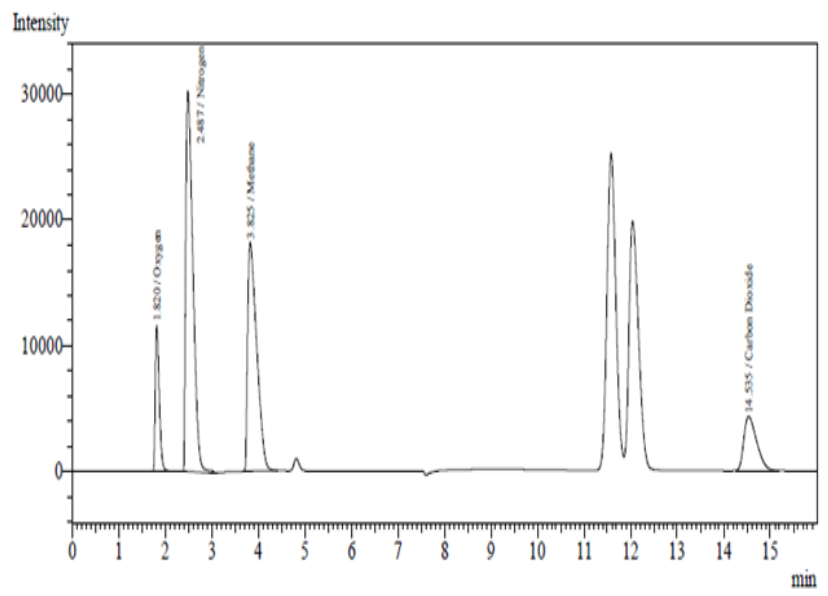

\begin{tabular}{|r|l|r|r|r|r|}
\hline Peak $\#$ & Name & Ret.Time & \multicolumn{1}{|c|}{ Area } & Conc. & Units \\
\hline 1 & Oxygen & 1.820 & 69443 & 6.07 & $\%$ Mol \\
\hline 2 & Nitrogen & 2.48 & 324558 & 17.29 & $\%$ Mol \\
\hline 3 & Methane & 3.825 & 247704 & 53.83 & $\%$ Mol \\
\hline 4 & CarbonDioxide & 14.535 & 82799 & 22.81 & $\%$ Mol \\
\hline Total & & & & 100.00 & \\
\hline
\end{tabular}

Figure 3. Biogas Composition Analysis Result From Cow Manure and POME at $25^{\text {th }}$ day

All biogas composition analysis results from cow manure and POME for 35 days of fermentation can be seen in Table 2.

Table 2. Biogas Composition Analysis Result From Cow Manure and Slurry

\begin{tabular}{|c|c|c|c|c|}
\hline Day & \multicolumn{4}{|c|}{ Biogas Composition (\%) } \\
\hline & $\mathrm{CH}_{4}$ & $\mathrm{CO}_{2}$ & $\mathrm{O}_{2}$ & $\mathrm{~N}_{2}$ \\
\hline 0 & 0 & 0 & 0 & 0 \\
\hline 5 & 24.61 & 4.67 & 21.52 & 49.2 \\
\hline 10 & 29.47 & 8.42 & 19.07 & 42.84 \\
\hline 15 & 37.53 & 13.28 & 17.44 & 31.75 \\
\hline 20 & 45.06 & 16.92 & 16.28 & 21.74 \\
\hline 25 & 53.83 & 22.81 & 6.97 & 17.29 \\
\hline 30 & 51.72 & 32.16 & 5.59 & 10.53 \\
\hline
\end{tabular}

From the analysis of the composition of the gas above the mixture of cow manure and POME raw materials produces higher methane gas content compared to the mixture of cow manure and slurry raw materials which can be seen in Figure 2. Where POME has a high content of organic compounds which is shown by the COD value of $41200 \mathrm{ppm}$ which is a source of nutrition for microorganisms in the anaerobic fermentation process. 


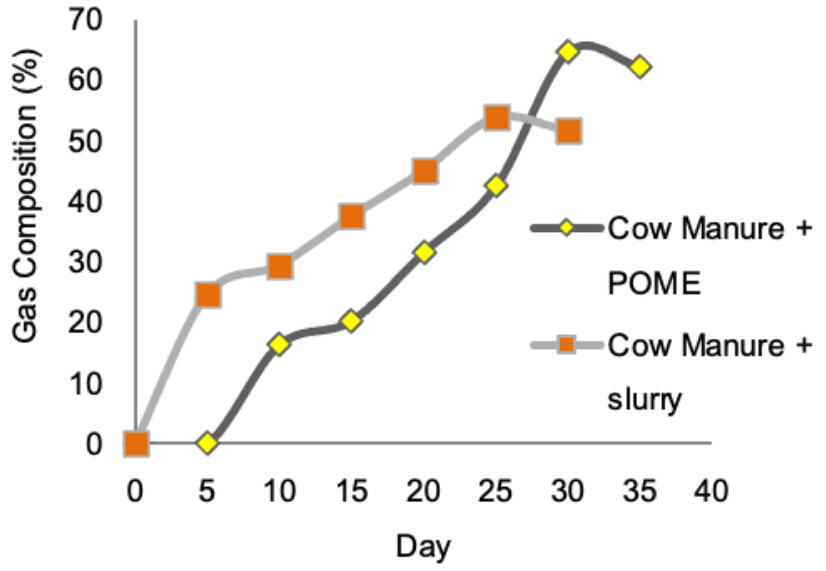

Figure 4. Comparisons of methana gas composition

According to [27], the addition of POME to biogas with cow dung can improve the composition of methane gas. In a mixture of $70 \%$ POME and $30 \%$ cow dung, the composition of methane gas was $61.13 \%$.

\subsection{Biogas Volume Analysis}

The results of measurements of the total volume of biogas production produced in a mixture of cow manure and POME raw materials were 54 liters for 35 days of fermentation with a peak of biogas production of 16 liters on the 25 th day which can be seen in Table 3 .

Table 3. Biogas Production Result From Cow Manure and POME

\begin{tabular}{|c|c|}
\hline Day & Biogas Production (Liter) \\
\hline 0 & 0 \\
\hline 5 & 0 \\
\hline 10 & 2 \\
\hline 15 & 6 \\
\hline 20 & 10 \\
\hline 25 & 20 \\
\hline 30 & 16 \\
\hline 35 & 8 \\
\hline
\end{tabular}

Whereas in the mixture of raw material for cow dung and slurry, the amount of biogas production volume is greater, that is 58 liters for 30 days of fermentation and the peak of biogas production is 16 liters on the 20th day which can be seen in Table 4 .

Table 4. Biogas Production Result From Cow Manure and slurry

\begin{tabular}{|c|c|}
\hline Day & Biogas Production (Liter) \\
\hline 0 & 0 \\
\hline 5 & 4 \\
\hline 10 & 8 \\
\hline 15 & 10 \\
\hline
\end{tabular}

\begin{tabular}{|c|c|}
\hline 20 & 16 \\
\hline 25 & 12 \\
\hline 30 & 8 \\
\hline
\end{tabular}

From the measurement of biogas production volume produced above the mixture of cow manure and slurry raw materials produce biogas faster and produce a greater amount of biogas compared to the mixture of cow manure and POME raw materials which can be seen in Figure 5.

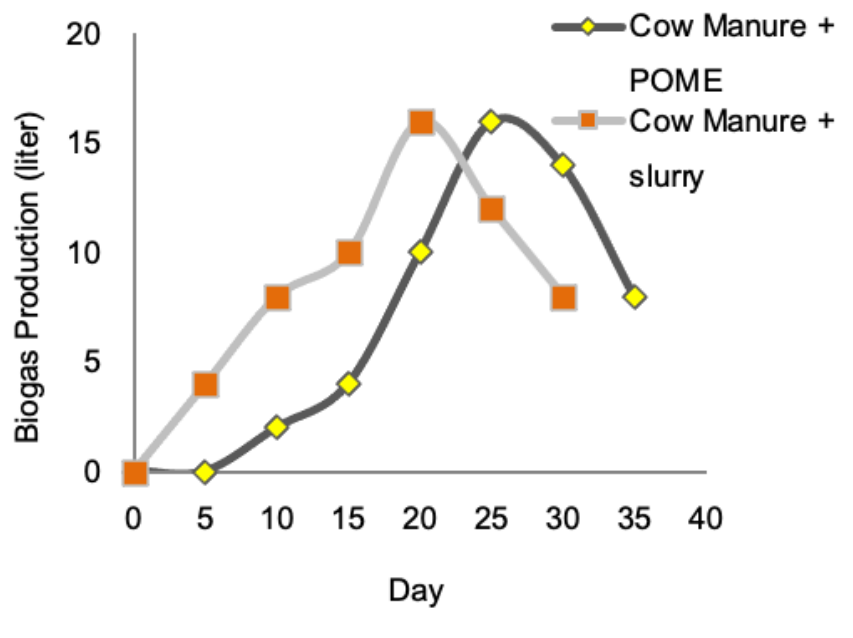

Figure 5. Comparisons of Biogas Production

The addition of biogas slurry to the biogas raw material mixture did not have much effect on the biogas production results. In addition, biogas slurry mixture of $80 \%$ on raw materials biogas generating biogas production amounted to $21,891 \mathrm{~mL}$ in which only increased by $11.21 \%$ yield from biogas production without biogas slurry mixture. The addition of biogas slurry can also increase the potential for methane production from the anaerobic digestion process. In addition, biogas slurry by $80 \%$ in the mixture of raw material produces methane gas production is higher compared to other mixture that is equal to $61.21 \%$ at day 23 and produce methane gas faster than without the addition of biogas slurry [24].

\section{CONCLUSION}

This research shows that making biogas from cow manure raw materials with the addition of POME and slurry can increase the composition of methane gas and biogas production produced. Where the addition of POME produces $64.65 \%$ of methane gas with biogas production of $54 \mathrm{~L}$ and the addition of biogas slurry produces methane gas of $53.83 \%$ with biogas production of $58 \mathrm{~L}$. This shows that biogas has great 
potential as an environmentally friendly renewable energy source and economical.

\section{ACKNOWLEDGMENTS}

The author thanks Iqbal Nur Daiyan, Leila Kalsum, A. Husaini, and Rusdianasari for their contribution to this study. Thank you also to PT. Pupuk Sriwidjaja Palembang and Politeknik Negeri Sriwijaya for the facilities in this study.

\section{REFERENCES}

[1] Anindhita, I. Rahardjo, I. Fitriana, and R. Etie Puspita Dewi, Outlook Energi Indonesia 2018. Jakarta: Pusat Pengkajian Industri Proses dan Energi (PPIPE) Badan Pengkajian dan Penerapan Teknologi (BPPT), 2018.

[2] R. Ploetz, Rusdianasari, and Eviliana, "Renewable Energy: Advantages and Disadvantages," Proceeding Forum Res. Sci. Technol., vol. Vol. 3, no. Issue 1, pp. 1-4, 2016.

[3] R. A. Nurul Moulita, Rusdianasari, and L. Kalsum, "Converting Waste Cooking Oil into Biodiesel using Microwaves and High Voltage Technology," in Journal of Physics: Conference Series, 2019, vol. 1167, no. 1. DOI: https://doi.org/ 10.1088/1742-6596/1167/1/012033

[4] S. Yunsari, Rusdianasari, and A. Husaini, "CPO Based Biodiesel Production using Microwaves Assisted Method," in Journal of Physics: Conference Series, 2019, vol. 1167, no. 1. DOI: https://doi.org/10.1088/1742-6596/1167/1/012036

[5] P. Dilia, K. Leila, and R. Rusdianasari, "Fatty Acids from Microalgae Botryococcus braunii for Raw Material of Biodiesel," in Journal of Physics: Conference Series, 2018, vol. 1095, no. 1. DOI: https://doi.org/10.1088/1742-6596/1095/1/012010

[6] Rusdianasari, A. Syarif, M. Yerizam, M. S. Yusi, L. Kalsum, and Y. Bow, "Effect of Catalysts on the Quality of Biodiesel from Waste Cooking Oil by Induction Heating," in Journal of Physics: Conference Series, 2020, vol. 1500, no. 1. DOI: https://doi.org/10.1088/1742-6596/1500/1/012052

[7] Suminto, D. A. Susanto, R. Lukiawan, B. S. Nasional, and G. M. Wanabakti, "Standards Requirement in Supporting the Development of New Energy Sources (Biogas)," pp. 9-19, 2013.

[8] R. J. Teodorita Al Seadi, Domiik Rutz, Heinz Prassl, Michael Kottner, Tobias Finsterwalder, Silke Volk, biogas HANDBOOK. Esbjerg: University of Southern Denmark Esbjerg, Niels
Bohrs Vej 9-10, DK-6700 Esbjerg, Denmark, 2008.

[9] Fachagentur Nachwachsende Rohstoffe e. V., Guide to Biogas: From production to use. Eschborn: Fachagentur Nachwachsende Rohstoffe e. V. (FNR) FNR, 2012.

[10] S. S. Mulyawan, D. W. Aghnia, E. Rianawati, and E. Damanhuri, "The Study of Rice Husk as CoDigestion Together with Cow Dung is Biogas Production of Anaerobic Digester," vol. 13, 2018. DOI: https://doi.org/10.1051/e3sconf/20187301013

[11] M. Stucki, Matthias; Jungbluth, Niels; Leuenberger, "Life Cycle Assessment of Biogas Production from Different Substrates," ESUservices Ltd., p. 84, 2011.

[12] H. Hadiyanto and R. Hendroko, "Integrated Biogas-Microalgae from Waste Waters as the Potential Biorefinery Sources in Indonesia," Energy Procedia, vol. 47, pp. 143-148, 2014. DOI: https://doi.org/10.1016/j.egypro.2014.01.207

[13] M. Khalil, M. Ali, R. Heryanto, and A. Rizalie, "Waste to energy technology: The potential of sustainable biogas production from animal waste in Indonesia," Renew. Sustain. Energy Rev., vol. 105, no. July 2018, pp. 323-331, 2019. DOI: https://doi.org/10.1016/j.rser.2019.02.011

[14] Sajaruddin, L. Kalsum, and Z. Muchtar, "The Analysis of Biogas Fermentation Time from Cow Manure on Fixed Dome Biodigester Batch Systems," in Journal of Physics: Conference Series, 2020, vol. 1500, no. 1. DOI: https://doi.org/10.1088/1742-6596/1500/1/012043

[15] S. Varqa, "Essential Palm Oil Statistics Palm Oil Analytics," Palm Oil Anal., p. 7, 2017.

[16] Y. Ahmed, Z. Yaakob, P. Akhtar, and K. Sopian, "Production of biogas and performance evaluation of existing treatment processes in palm oil mill effluent (POME)," Renew. Sustain. Energy Rev., vol. 42, pp. 1260-1278, 2015. DOI: https://doi.org/ 10.1016/j.rser.2014.10.073

[17] Susilawati and Supijatno, "Waste Management of Palm Oil (Elaeis guineensis Jacq.) in Oil Palm Plantation, Riau," vol. 3, no. 2, pp. 203-212, 2015.

[18] M. N. Uddin, M. A. Rahman, J. Taweekun, and M. Mofijur, "Enhancement of biogas generation in sludge blanket (UASB) bioreactor from palm oil mill effluent ( POME )," Energy Procedia, vol. 160, pp. 670-676, 2019. DOI: https://doi.org/ 10.1016/j.egypro.2019.02.220 
[19] H. S. Tira, Syahrul, and E. G. Umbara, "Evaluasi efektifitas effective microorganism-4 (EM-4) dalam menaikkan volume produksi biogas," Din. Tek. Mesin, vol. 8, no. 1, pp. 40-44, 2018. DOI: https://doi.org/ 10.29303/d.v8i1.40

[20] L. Kalsum, A. Hasan, Rusdianasari, A. Husaini, and Y. Bow, "Evaluation of Main Parameter Process of Anaerobic Digestion of Cow Dung in Fixed Dome Biodigester on Methane Gas Quality," in Journal of Physics: Conference Series, 2020, vol. 1500, no. 1. DOI: https://doi.org/ $10.1088 / 1742-6596 / 1500 / 1 / 012060$

[21] S. Saelor, P. Kongja, and S. O-Thong, "Biogas Production from Anaerobic of Palm Effluent and Empty Fruit Bunches," Energy Procedia, vol. 138, pp. 717-722, 2017. DOI: https://doi.org/ 10.1016/j.egypro.2017.10.206

[22] S. Krishnan et al., "Comparison of process stability in methane generation from palm oil mill effluent using dairy manure as inoculum," Environ. Technol. Innov., vol. 8, pp. 360-365, 2017. DOI: https://doi.org/10.1016/j.eti.2017.08.005
[23] Suhubdy, Skenario Pengembangan Ternak Kerbau dan Sapi di Indonesia. 2017.

[24] H. Wang, J. Xu, L. Sheng, and X. Liu, "Effect of addition of biogas slurry for anaerobic fermentation of deer manure on biogas production," Energy, vol. 165, pp. 411-418, 2018. DOI: https://doi.org/ 10.1016/j.energy.2018.09.196

[25] J. Ning et al., "Simultaneous biogas and biogas slurry production from co-digestion of pig manure and corn straw: Performance optimization and microbial community shift," Bioresour. Technol., vol. 282, pp. 37-47, 2019. DOI: https://doi.org/ 10.1016/j.biortech.2019.02.122

[26] Suminto, D. A. Susanto, R. Lukiawan, B. S. Nasional, and G. M. Wanabakti, "Standards Requirement in Supporting the Development of New Energy Sources (Biogas),” pp. 9-19, 2013.

[27] U. Sidik, F. Razali, S. Alwi, and F. Maigari, "Biogas production through Co-digestion of palm oil mill effluent with cow manure," Niger. J. Basic Appl. Sci., vol. 21, no. 1, pp. 79-84, 2013. DOI: https://doi.org/10.4314/njbas.v21i1.12 